Thorax, 1980, 35, 523-525

\title{
Defective yeast opsonisation of serum in tuberculosis
}

\author{
N McI JOHNSON, M W McNICOL, A KAPOOR, J E BURTON-KEE, AND J F MOWBRAY
}

From the Willesden Chest Clinic, and St Mary's Hospital Medical School, London

ABSTRACT We have studied the opsonising ability of the sera of 92 patients with tuberculosis. Fourteen per cent of these patients showed defective opsonising ability compared with $4 \%$ in a clinic control group. This increased frequency in TB was accounted for by the greatly increased proportion with defects found in patients with intrathoracic TB $(21 \%)$. We may have identified a section of the population with a specific genetically linked abnormality of a host defence mechanism which renders them more susceptible to intrathoracic TB. Further population studies are required.

In recent years the incidence of tuberculosis in some parts of Britain has increased, almost entirely because of the higher incidence in the immigrant population. Various explanations have been proposed. One possibility is that this increase is caused by a defect in one or more of the host defence mechanisms of these patients. We have studied one such mechanism, serum opsonisation, in Willesden-an area of London with both a large immigrant population and a relatively high prevalence of TB.

Opsonisation prepares circulating microorganisms for phagocytosis. This occurs either through an immune pathway requiring IgG and the classical complement pathway or by a rapid non-immune pathway, which requires a serum factor and the alternative pathway of complement. There is a genetically linked defect of this latter non-immune pathway in approximately $5 \%$ of the general population, in that the sera from these patients fail to opsonise yeast for phagocytosis by normal human polymorphonuclear leucocytes. This defect of the effector arm of the host defence mechanism is found excessively frequently both in children with recurrent infections $^{1}$ and in adults with sarcoidosis. ${ }^{2} \mathrm{We}$ have, therefore, studied patients with tuberculosis for this defect.

\section{Methods}

Blood was taken from 92 patients in whom tuberculosis had been diagnosed. These were chosen at random from patients attending Willesden Chest Clinic. A control group of 46 patients with no

Address for reprint requests: Dr NMcI Johnson, Medical Unit Middlesex Hospital, Mortimer Street, London W1.
Table 1 Patients studied

\begin{tabular}{lll}
\hline & Tuberculosis patients & Clinic control subjects \\
\hline Number & 92 & 46 \\
Sex & $39 \mathrm{M} 53 \mathrm{~F}$ & $22 \mathrm{M} 42 \mathrm{~F}$ \\
Mean age (yr) & 37 (range 4-80) & 31 (range 14-74) \\
Race & & \\
$\quad$ Indian & $77(84 \%)$ & $28(61 \%)$ \\
Caucasian & $9(10 \%)$ & $7(15 \%)$ \\
Negro & $4(4 \%)$ & $11(24 \%)$ \\
Chinese & $2(2 \%)$ & - \\
\hline
\end{tabular}

evidence of TB attending Willesden Chest Clinic for BCG were studied. This group had a racial distribution similar to the patients (table 1). A group of 45 unmatched laboratory staff was also tested.

Sera were separated within four hours of collection and stored at $-70^{\circ} \mathrm{C}$ until analysed.

The opsonisation test used was a slight modification of that described by Levinsky et al." Ten $\mu \mathrm{l}$ of yeast particles and $10 \mu \mathrm{l}$ of normal human polymorphonuclear leucocytes with a ratio of yeast polymorphs $5: 1$ were mixcd together with $5 \mu \mathrm{l}$ of test serum in a Luckham plastic tube and the reaction mixture was made into a total volume of $200 \mu \mathrm{l}$, with barbitone buffer ( $\mathrm{pH} \mathrm{7.6)}$ with calcium $(10 \mathrm{mM})$ and magnesium $(10 \mathrm{mM})$. The mixture was incubated at $37^{\circ} \mathrm{C}$ for 30 minutes on a rotating mixer. Control samples of $10 \mu \mathrm{l}$ of yeast particles were made up to the same reaction volume and also incubated. Known samples of normal and defective sera were also included in each batch. After incubation the reaction mixture was diluted $1: 500$ with an automatic diluter (Compupet, Warner Diagnostics). The red cells were lysed by the addition of a drop of Zaponin (Coulter Electronics, Harpenden) to each assay tube and the number of unphago- 
cytosed yeast particles were counted in a Coulter counter. The results were expressed as a percentage uptake of yeast particles by the normal polymorphs.

$$
\begin{aligned}
& \text { Pecentage uptake }=\left(t-\frac{y}{t}\right) \times 100 \\
& t=\text { total number of yeast particles } \\
& y=\text { number unphagocytosed }
\end{aligned}
$$

Immune complexes were precipitated with $2 \%$ polyethyleneglycol and the $\mathrm{Clq}$ and immunoglobulins determined by radial immunodiffusion. ${ }^{4}$ CH50 was measured by a standard functional assay, using sensitised sheep red cells, and C3 by single radial immunodiffusion. The antisera were raised in rabbits by immunisation with purified components, and standardised by comparison with relevant antisera.

\section{Results}

The sera from $13(14 \%)$ of the 92 patients with TB had defective opsonising ability, whereas only $2(4 \%)$ of the 46 clinic control subjects had this defect (figure, table 2). As the frequency of the defect was the same in both the racially matched and unmatched control groups, the results were pooled to obtain a group of similar size to that of the patients with TB. In this pooled control group, five of 89 sera were defective, significantly less than in the TB group. ( $p=0.03$ Fisher's exact test).

When the site of disease was considered (table 3 ), the increased frequency of the defect was almost entirely confined to patients with lung disease $(21 \%)$ or hilar or mediastinal lymph node enlargement $(21 \%)(p<0.05$ Fisher's exact test). In patients with peripheral node, pleural, or bone disease the frequency of the defect was normal.

The defect was increased in all racial groups studied (table 4).

Complement values were normal in individual patients and in the groups taken as a whole (table 5).

When an assessment was made as to the severity and activity of tuberculosis there appeared to be $\overrightarrow{\bar{B}}$ no difference between the patients with thiso defect and those without, nor did the presence $\frac{}{0}$ of this defect relate to response to therapy.

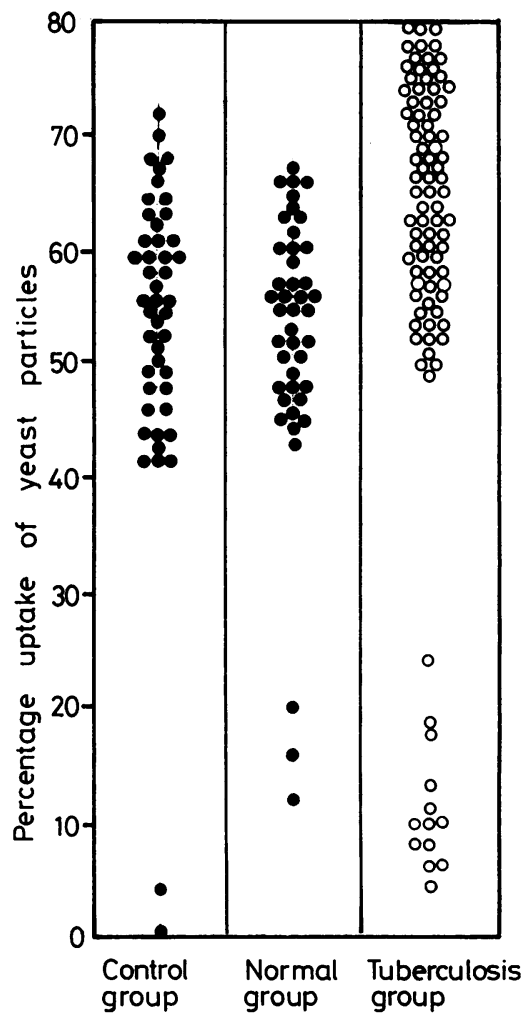

Figure Uptake of yeast particles by normal polymorphs in BCG clinic control subjects, normal

\begin{tabular}{|c|c|c|c|}
\hline & \multicolumn{2}{|l|}{ Defect } & \multirow[t]{2}{*}{ Total } \\
\hline & Number & $\%$ & \\
\hline $\begin{array}{l}\text { All patients with TB } \\
\text { Clinic control subjects } \\
\text { Laboratory control subjects } \\
\text { Pooled controls }\end{array}$ & $\begin{array}{l}13 \\
2 * \\
3 \\
5+\end{array}$ & $\begin{array}{r}14 \\
4 \\
7 \\
5\end{array}$ & $\begin{array}{l}92 \\
46 \\
43 \\
89\end{array}$ \\
\hline
\end{tabular}
laboratory staff, and patients with tuberculosis.

Table 2 Opsonising defect in tuberculosis

* Statistical difference from TB patients $p=0.05$ Fisher's exact test.

\begin{tabular}{|c|c|c|c|c|c|c|c|}
\hline \multirow[t]{2}{*}{ Opsonisation } & \multirow[t]{2}{*}{ Control subjects } & \multirow[t]{2}{*}{ All TB patients } & \multicolumn{5}{|l|}{ Site } \\
\hline & & & Lung & Hilar or mediastinal glands & Extrathoracic nodes & Pleura & Bone \\
\hline $\begin{array}{l}\text { Total } \\
\text { Normal } \\
\text { Defective }\end{array}$ & $\begin{array}{r}46 \\
44 \\
2\end{array}$ & $\begin{array}{l}92 \\
79 \\
13^{*}\end{array}$ & $\begin{array}{l}34 \\
27 \\
7^{*}\end{array}$ & $\begin{array}{l}23 \\
18 \\
5 *\end{array}$ & $\begin{array}{r}35 \\
34 \\
1\end{array}$ & $\begin{array}{l}6 \\
6 \\
0\end{array}$ & $\begin{array}{l}7 \\
7 \\
0\end{array}$ \\
\hline
\end{tabular}
+ Statistical difference from TB patients $\mathrm{p}=\mathbf{0 . 0 3}$ Fisher's exact test.

Table 3 Opsonising defect and site affected by tuberculosis 
Table 4 Racial distribution of defect

\begin{tabular}{lll}
\hline Race & Tuberculosis patients & Control subjects \\
\hline Indian & $8 / 77$ & $1 / 28$ \\
Caucasian & $2 / 9$ & $1 / 7$ \\
Negro & $3 / 4$ & $0 / 11$ \\
Chinese & $0 / 2$ & - \\
\hline
\end{tabular}

Table 5 Complement values

\begin{tabular}{|c|c|c|c|c|}
\hline & \multicolumn{2}{|c|}{$\begin{array}{l}\text { Tuberculosis patients } \\
(n=53)\end{array}$} & \multicolumn{2}{|c|}{$\begin{array}{l}\text { Control subjects } \\
(n=46)\end{array}$} \\
\hline & Mean* & $\pm S D$ & Mean* & $\pm S D$ \\
\hline $\begin{array}{l}\text { CH50 } \\
\text { C3 }\end{array}$ & $\begin{array}{r}98 \\
102\end{array}$ & $\begin{array}{l}12 \\
13\end{array}$ & $\begin{array}{l}106 \\
102\end{array}$ & $\begin{array}{l}7 \\
9\end{array}$ \\
\hline
\end{tabular}

* Expressed as percentage of control pool of normal sera. Differences between control subjects and tuberculosis patients not significant.

\section{Discussion}

We found an increased frequency of this defect of opsonisation in the serum of patients with tuberculosis, accounted for by the marked increase $(21 \%)$ in those patients with intrathoracic disease. The frequency of the defect was increased in all races studied, therefore racial selection is unlikely to account for our findings.

It may be argued that defects of the alternative pathway of complement through congenital lack of complement components or consumption of complement might cause defective opsonisation. However, the values of serum complement in individual cases and in groups as a whole were normal.

The presence of this defect in tuberculosis seems to be of little prognostic significance in that the disease responded satisfactorily to therapy in all cases, and patients with this defect did not appear to have the disease more severely than those without. The reason why patients with this defect should have intrathoracic rather than extrathoracic disease is uncertain, but it is interesting that in a previous study the patients with sarcoidosis who had this defect had a tendency towards pulmonary infiltration. ${ }^{2}$

It is known that the opsonising defect is genetically controlled and may be associated with gene products of the HLA region of the sixth chromosome. ${ }^{5}$ The molcular basis for the defect is unknown. Normal opsonisation can be restored by the addition of a small amount of normal plasma. ${ }^{16}$ Previous studies have shown this defect to be associated with frequent infection and allergy in childhood and atopy presented with infantile eczema or hay fever. ${ }^{15}$ Recent work has also shown there to be an association between this defect and sarcoidosis. ${ }^{2}$

We may have identified a section of the population with a specific genetic defect which renders them more susceptible to intrathoracic tuberculosis. Further population studies of large numbers of people with this defect are required.

\section{References}

1 Soothill JF, Harvey BAM. Defective opsonisation. A common immunity deficiency. Arch Dis Child 1976; 51:91-9.

2 Johnson NMcI, McNicol MW, Kapoor A, Burton-Kee EJ, Mowbray JF. Defective yeast opsonisation in sarcoidosis. Clin Sci 1979; 57:22p.

3 Levinsky RJ, Harvey BAM, Paleja S. A rapid objective method for measuring the yeast opsonisation activity of serum. J Immunol Methods 1978; 24:251-6.

4 Nydegger UE, Lambert PE, Gerber H, Miescher PA. Circulating immune complexes in the serum in systemic lupus erythematosus and in carriers of hepatitis B Antigen. Quantitation by binding to radiolabelled $\mathrm{C}_{\mathrm{lq}}$. J Clin Invest 1974; 54: 297-309.

5 Turner MW, Mowbray JF, Harvey BAM, Brostoff J, Wells RS, Soothill JF. Defective yeast opsonisation and $\mathrm{C}_{2}$ deficiency in atopic patients. Clin Exper Immunol 1978; 34:253-9.

6 Miller ME, Seals J, Haye R, Levitsky LC. A familial plasma associated defect of phagocytosis. Lancet 1968; 2:60-3. 